original authors who described welded-tuffs now use the term ash-flow, and use it to embrace everything from sillars to the classic ignimbrites, I cannot find a great deal of merit in retaining the distinction. Again we find that other authorities have extended the term ignimbrite: Steiner (Bull. Geol. Surv., N.Z., 68, 1960) implies a non-genetic usage, embracing both lavas and ignimbrites formed by Marshall's process (or a modification of it): Pantò (Acta Geologica, Budapest, 6, 307-331, 1962) retains the term only as a group namecover ing ignispumites (foam-lavas, froth-flows) and flood-tuffs (embracing sillars and what Rast would closely define as welded-tuffs and ignimbrites). Clearly the writer has a choice of terminology, but should clearly state which usage he follows. I myself restrict the term ignimbrite to rocks which have been formed by Marshall's process of deposition from a cloud or shower, use ash-flow to signify overland flow phenomena more closely related to the sandflow nuees ardentes than the Peleean type but involving lithostatic-load compaction effects to produce welding: while at present I am most attracted by Pantò's classification, I am not happy about extending the term ignimbrite so far from Marshall's original definition.

Pantò envisages two dissimilar processes showing convergent effects which result in suites of very similar flow-rocks, all of which he considers as ignimbrites. Rast and I both, apparently, accept the existence of foam lavas. Rast considers the compaction welding phenomenon as an established fact: I believe that relationships such as he considers certain criteria of compaction welding may be capable of another explanation: the inferences which any of us may draw from evidence are always liable to reinterpretation by others more gifted than ourselves, or others with later-gleaned evidence at hand to them. And so I retain the belief that all the very similar rocks which Pantò considers as ignimbrites, and divides into foam lavas and flood-tuffs, may yet prove to have stemmed from a primary process of foaming and frothing in a lava, and may have never suffered lithostatic load compaction effects to produce flattened fiamme structures. But this is not inevitable.

Department of Geology,

Joseph MCCALL.

UNIVERSITY OF WESTERN AUSTRALIA. 19 th April, 1963.

\title{
PRE-CAMBRIAN PERTHOSITES IN NYASALAND
}

SIR,-Thanks to Dr. S. W. Morel for his reply (Geol. Mag., 99, 575) to my discussion (Geol. Mag., 99, 92). Unfortunately he has not been able to join in the discussion on the main point raised, i.e. on the evolution of the perthites in the rocks described by him (Morel, 1961). Dr. Morel's reply does not add any new data (on the perthites) which were lacking in his original paper. The feldspar, which is stated to have crystallized " after the directional forces had ceased" (Morel, 1961, 241) is again claimed to have suffered metamorphism and consequent exsolution (Morel, 1962, 575). The idea that the original feldspar was anorthoclase, should find support with more data. It would be interesting to know the details of the perthites formed by deformation, and which apparently resemble the perthites of magmatic origin, as noted in my discussion. Dr. Morel (1961) did not make any firm statement regarding para-kinematic origin of the rocks, the idea expressed now in words of other authors (Morel, 1962, 575). In general, Dr. Morel's observations need clarification regarding the nature, composition, and origin of the perthites and their time relation with deformation. It is interesting to note further that he is now inclined towards a metasomatic origin of the perthitic rocks.

\section{REFERENCE}

Morel, S. W., 1961. Pre-cambrian perthosites in Nyasaland. Geol. Mag., 98, 235-244.

DepartMent of Geology,

MiHIR K. Bose.

Presidency College, Calcutta. 19th March, 1963. 